\title{
EFFECTS OF SAVANNAH CONSERVATION ON THE FLORISTIC DIVERSITY AND STRUCTURE OF SPECIES CHARACTERISTICS OF THE SAVANNAS OF MANZONZI IN DEMOCRATIC REPUBLIC OF CONGO
}

\author{
MBANGILWA, M. M. ${ }^{1}$ - MALOTIE, J. M. ${ }^{2}-$ KASORO, R. F. ${ }^{3}-$ JIANG, L. C..$^{*}$ \\ ${ }^{1}$ Key Laboratory of Sustainable Forest Ecosystem Management, Ministry of Education, School \\ of Forestry, Northeast Forestry University, Harbin 150040, P.R China \\ ${ }^{2}$ Post-university Regional School for Integrated Management and Management of Tropical \\ Forests and Territories (ERAIFT), University of Kinshasa, B.P. 15.373 Kinshasa, Democratic \\ Republic of Congo \\ ${ }^{3}$ College of Resources and Environment Sciences, Jilin Agricultural University, 2888 Xincheng \\ St, Nanguan, Changchun, Jilin, P.R. China \\ ${ }^{*}$ Corresponding author \\ e-mail: jlichun@nefu.edu.cn
}

(Received $1^{\text {st }}$ Aug 2019; accepted 25 ${ }^{\text {th }}$ Nov 2019)

\begin{abstract}
The variation of floristic diversity and the structure of the vegetation were observed in sixteen plots of one hectare each, eight of which were in the savannah set aside and eight in the one under fire. The study was limited to ligneous plants with a focus on regeneration in subplots installed in each plot. A statistical analysis and indices were employed to compare the results of the two treatments. On the floristic level, the savannah put under protection compared to that subjected to the fires is the most diversified (63 species compared to 17), and that its contact with the forest puts it in a situation of evolution. The density is higher in the defended savannah (406.3/ha) than in the burned savanna (256.3/ha) with a larger basal area $\left(5.3 \mathrm{~m}^{2} / \mathrm{ha}\right.$ against 2.3$)$. The analysis of similarity indicates that these two treatments are different floristically. The study also reveals that protection yields great economic, social and environmental benefits.
\end{abstract}

Keywords: density, subplots, plot, ligneous plants, basal area

\section{Introduction}

The structure and diversity of tropical vegetation are determined by the discontinuous distribution of several biotic and/ or abiotic factors, which act on different spatial and temporal scales (Dale, 1999; Peña-Claros et al., 2012; Arruda et al., 2015a; Rodrigues et al., 2016). However, African dry forest and woodland vegetation types are characterized by more or less continuous tree cover $(70 \%)$, prolonged drought lasting more than three months per year, and by their occurrence within the savanna biome (Menaut et al., 1995; Savadogo et al., 2007). They cover approximately 13 million $\mathrm{km}^{2}, 43 \%$ of the total area of the continent, and are divided into two distinct regions, in the northern hemisphere (Sudanian region) and the southern hemisphere (Zambezian region) (Savadogo et al., 2007).

Savannahs are complex ecosystems characterized by the coexistence of herbaceous strata and one or more shrub and / or tree layers under the effect of the interaction of several environmental factors: various rainfall patterns, the role of fire and fire breeding (Jacquin, 2010) as well as the nature of the soil. It is an open grassland formation composed mainly of perennial or annual grasses (Jacquin, 2010). Its vegetation may be purely grassy or scattered 
with shrubs or trees and varies with rainfall, soil and anthropogenic activity (Clément, 1982; Manlay et al., 2002). In the Democratic Republic of Congo (DRC), savannas cover 76.8 million hectares and are the second type of ecosystem after the dense forests that represent $10 \%$ of the world forests (Lubalega, 2016).

The ecology of savannas and the consequences of the fire regime of animal and plant species on the environment is one of the most important issues for conservation biology and ecological principles. Several ecological studies suggest that some species may survive in repeated fire regimes (Burrows, 2008; Guenon, 2010), however, more information is needed to better understand what kind of habitats they are associated with. The lack of in-depth studies on this issue makes it impossible to accurately assess the effect of bush fire and the management of its impacts on vegetation structure.

For a long time, ecologists have been fascinated by savannas because trees and grasses coexist, while competing mainly for the same resource, namely water, which is the main limiting factor (Walter, 1971; Scholes and Archer, 1997; Sankaran et al., 2004). Classical ecological theory, such as the competitive exclusion principle, predicts that only one vegetation type can survive in these conditions (Hutchinson, 1961; Tilman, 1982). To solve this conundrum, numerous experimental and modeling studies have explored the nature of tree-grass competition and coexistence (e.g., Walker and Noy-Meir, 1982; Scholes and Walker, 1993; Higgins et al., 2000; House et al., 2003; Sankaran et al., 2004; Bodena et al., 2015).

For this investigation, our hypothesis is that savannahs kept safe from fires become more stable and tend to contain more species, and increase in diameter and density of stems. On the other hand, fire savannas would contain a low density of arboreal trees, small trees and shrubs would be more common.

The objective of the present work was to evaluate the effects of the conservation of savannas subjected to the fire regime on the floristic diversity and the structure of their vegetation. Specifically, it is a question of analyzing and comparing the floristic diversity and the structure of the savannas put in defense for six years to those of the savannas subjected to the regime of different intensity.

\section{Materials and Methods}

\section{Study area and data}

This research was conducted in a savanna patch in the villages of Manzonzi and Mao (S $5^{\circ} 43^{\prime} 45^{\prime \prime}$ - E $13^{\circ} 15^{\prime} 0^{\prime \prime}$ ), a few km south of the UNESCO Man and Biosphere Reserve of Luki and approximately $30 \mathrm{~km}$ north of the city of Boma (Lower Congo province, Democratic Republic of the Congo, hereafter referred to as DRC). The region of Bas-Congo (currently Kongo Centrale) has a tropical climate characterized by two distinct seasons: a dry season and a rainy season. The dry season is well marked with a season that goes from May to September, as well as a small dry season of 2 or 3 weeks in February (Quinif, 1986). According to the Köppen Classification, this phytogeographical region of Congolese Mayombe forest belongs to the AW4 system (Deklerck, 2019). Average annual rainfall is between 1200 - $1400 \mathrm{~mm}$ (Sys, 1960). However, the current data collected in the Luki (plateau) climatological station places it in the Aw5 system, unlike Sys (1960), where the first rains are not expected until mid-October and the annual averages hardly reach $1100 \mathrm{~mm}$.

The Mayombe climate of which Manzonzi is a part depends on the Atlantic Ocean, it is influenced by the cold Benguela current and the Southeast trade winds (Lubini, 1997). This cold marine current of Benguela is responsible for the small dry season rains known locally as 
"masala" (Kapa et al., 1987). These so-called occult rains (De Foresta, 1990) are expected towards the end of the August month, and plays the role of compensation of soil water deficit. We meet a dry season (May-September) and a rainy season (September-May) with a small dry season of 2 or 3 weeks in February (Quinif, 1986). The dry season is characterized by a slight drop in temperature due to frequent morning fogs or mists. For this work, the meteorological data (Figure 1) relate to the general situation of the Luki Biosphere Reserve (RBL), as the site under study (Manzonzi) generally enjoys the same conditions.

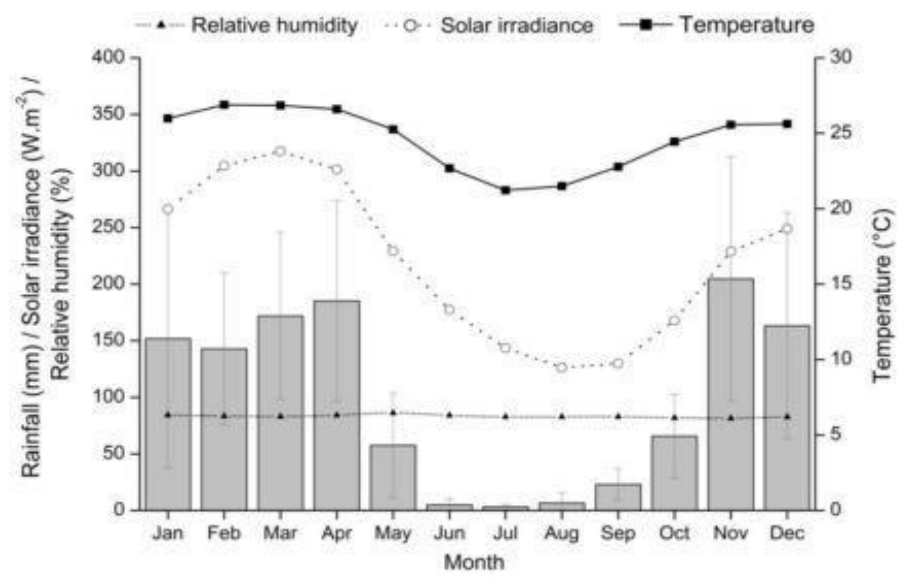

Figure 1. Climate diagram of the Luki meteorological station, Democratic Republic of Congo: monthly means of rainfall ( $\pm S D$ ), temperature, air humidity (1959-2006) and solar irradiance (1959-1994) (Couralet et al., 2010b)

The Mayombe extends from Gabon through Angola (Cabinda) to the Democratic Republic of Congo (DRC). The Mayombe range has a four-storey geological structure, the most recent of which is the West-Congolian floor (Lubini, 1997). It is formed by Middle Precambrian volcanic and metamorphic rocks (Quinif, 1986). It includes schisto-sandstone and schist-limestone systems (Lubini, 1997). Thus, shales, quartzites, graphitic rocks, feldspathic sandstones, micaschists, muscovites, amphiboloschists and intrusive rocks are observed. These various rocks have allowed the formation of the various types of soils encountered there. Most of the soil consists of ferrasols on undefined rocks (Sys, 1960). The rock formations are covered with a layer of surface soils of thickness ranging from $20 \mathrm{~cm}$ to $3 \mathrm{~m}$. These eluvia or colluvium derives from the underlying or surrounding geological basement (Sys, 1960).
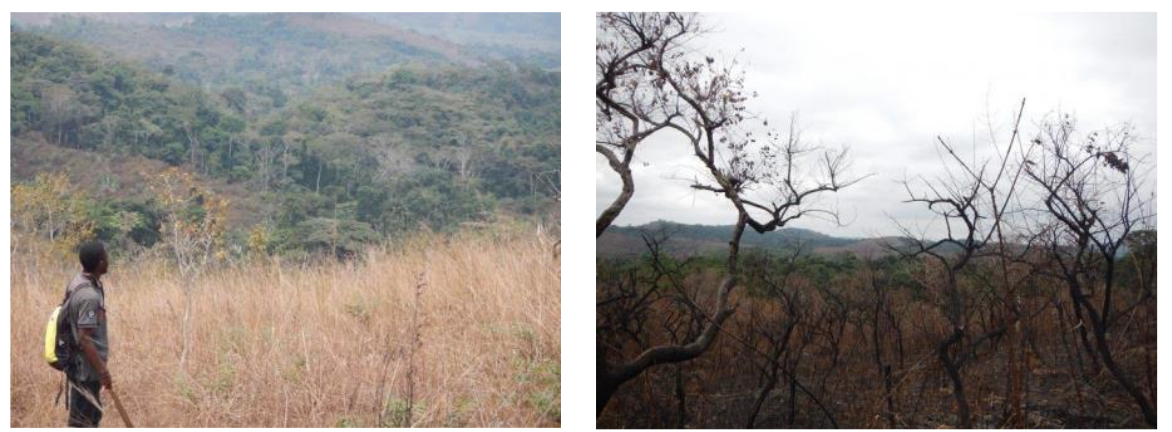

Figure 2. Image of Manzonzi savanna plots around the Luki Biosphère reserve in Bas-Congo (Source: Field investigation) 


\section{Data and methods}

\section{Selection of inventory sites}

In 2010, WWF proceeded with the opening of the variable-length transect according to the physiognomy of the site to be used for systematic inventories to characterize the large plant formations in this Manzonzi savannah (Figure 3). A total of 101 plots of 80 $\mathrm{m} \times 50 \mathrm{~m}$ each and $20 \mathrm{~m}$ apart from each other were placed there. This device has the advantage of capturing the heterogeneity of the ecological gradients of the environments traversed and of probing the homogeneous superimposed surfaces.

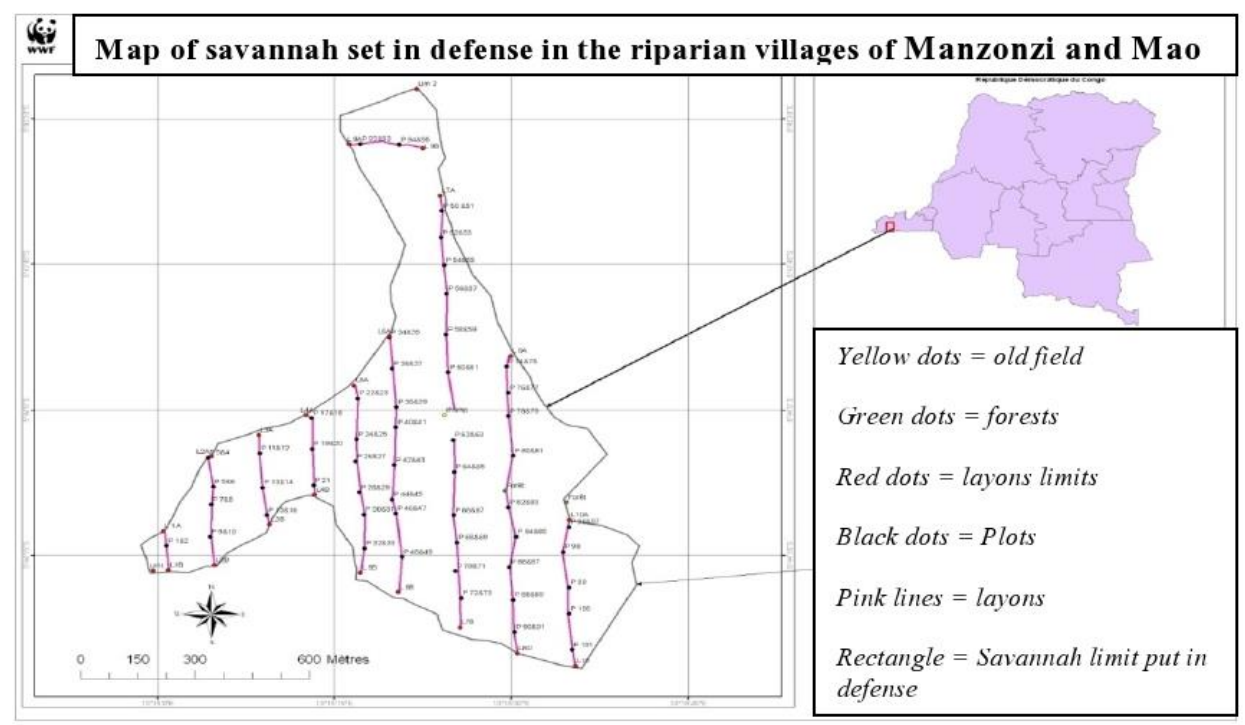

Figure 3. Systematic inventory system in the savannah of Manzonzi

For the present study conducted in June 2018, we have through this device set up a stratified sampling of plots distributed in the savannah and in the edge. The selection of firewood savanna (SRF) plots was based on annual fire passage, and populations were consulted for this choice. Plots were placed in a given orientation, indicated by the compass. Three vegetation formations have been identified: edge, savanna and grassy savannah. Each starting point of the plots is materialized by a stake bearing the number of the plots of inventory. The distance marking stakes were made from the stems of the small trees harvested on site and were placed every $50 \mathrm{~m}$. Depending on the slope, a certain distance was added in order to have a real horizontal distance corresponding to the length sought for the plots (SPIAF, 2007). All plots were geo-referenced using a GPS and a tracking was done for the savannah defensive (SMD). The tracking data included in the Geographic Information System (GIS) allowed us to use the ARC GIS 9.2 software to produce the site map under study (Figure 4).

\section{Botanical inventory and data collection}

Eight other plots of 1 ha each were installed in the savannah set aside and another eight in the savannas under fire following the same vegetation, in order to ensure the representativeness of the plots (Devineau et al., 1984; Favrichon et al., 1998), and their 
diversity (Dibi et al., 2008). The inventory concerned only ligneous plants (trees and shrubs), other plant forms (lianas, herbs...) were assessed qualitatively (Favier et al., 2004).

The location of the plots took into account the topographic features of the environment, the physiognomy of the vegetation and the fact that they significantly include ligneous plants of different heights. All species in plots were surveyed (Favier et al., 2004; Dibi et al., 2008) and all trees $\geq 20 \mathrm{~cm}$ measured (Duarte et al., 2006). The use of the ribbon was preferred to the forest compass because of the ease of work and the fact that the circumference gives a better estimate of the volume than that obtained by the compass (Rondeux, 1993).

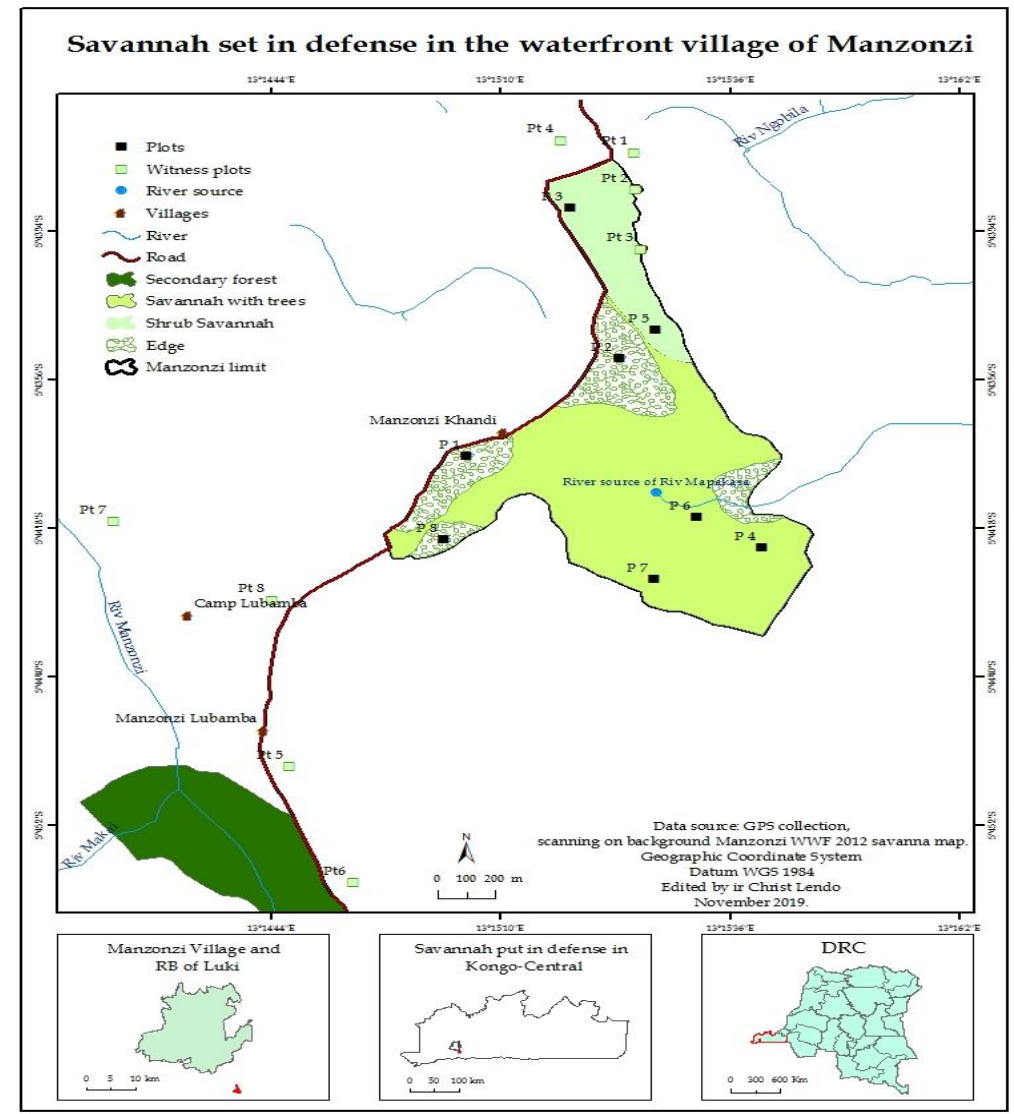

Figure 4. Layered inventory device in the savanna laid out in Manzonzi defenses

In each plot, a $10 \times 10 \mathrm{~m}$ sub-plot was installed to assess the regeneration of woody species in the herbaceous layer. All seedlings whose total height did not exceed $30 \mathrm{~cm}$ were identified and counted. For seedlings exceeding $30 \mathrm{~cm}$ in height and with a circumference less than $20 \mathrm{~cm}$, their diameter was measured using a caliper at the neck of the stem.

\section{Analytical and statistical approaches to the data}

\section{Analysis of floristic composition and vegetation structure}

The vegetation structure for these two types of treatment (SMD and SRF) was described by the calculation of non-parametric indices or structural indices, including: relative density, relative frequency, relative dominance, and value index importance of species and families (Mueller-Dombois and Ellenberg, 1974). These different indices have been calculated by the formulas below: 
The relative density (DER) of the stand that is representative of the number of individuals of each species or each family:

$$
D E R=100 \times \frac{\text { Number of individuals of a species or family }}{\text { Total number of individuals in the sample }}
$$

Relative dominance (DOR) that is representative of the basal area of each family or species:

$$
D O R=100 \times \frac{\sum \text { Basal area of individuals of species or families }}{\sum \text { Basal area of individuals of all species or families }}
$$

The relative frequency (FRR) that is representative of the dispersal of individuals in the field (the frequency of a species or the number of occurrences of a species, the number of plots in which the species is present.

$$
F E R=100 \times \frac{\text { Number of frequencies of a species or family }}{\text { Total number of frequencies }}
$$

Relative diversity (DIR) that is representative of the number of species in a family:

$$
D I R=100 \times \frac{\text { Number of species in a family }}{\text { Total number of species }}
$$

Significance value indices:

$$
\begin{aligned}
& I V I D O R+D E R+F R R / 3 \text { (for a species) } \\
& V F I=D O R+D E R+D I R \text { (for a family) }
\end{aligned}
$$

The Value of Significance of Species index gives information on the number of individuals, their distribution on the survey and their importance according to the basal area they occupy. In contrast, the PFD index provides information on the floristic importance of each family by the number of individuals in the family, the number of species representing the family, and the quantitative importance of families through the family of their terrific surfaces. This index makes it possible to highlight the most important species (Mueller-Dombois and Ellenberg, 1974; Kent and Coker, 1992).

Unlike previous indexes that can range from 0 to 100, it ranges from 0 to 300 (Doucet, 2003).

For a thorough analysis of the diversity of flora in these two types of treatment, we estimated:

(a) Sorensen Coefficient of Similarity $\left(C_{s}\right): C_{s}(s)=100[2 c /(a+b)]$ (Doucet, 2003; Dibi et al., 2008). With $a=$ number of species of medium $A, b=$ number of species of medium $\mathrm{B}, \mathrm{c}=$ number of species common to both ecological environments.

(b) The density of ligneous (D), which is expressed by the following formula: $N / S$ where, $\mathrm{N}=$ number of stems in the plots of the medium considered, $\mathrm{S}=$ total area of the plots in ha.

(c) The basal area (A), which is calculated according to the following expression: $A=$ $d^{2}\left(P_{1} / 4\right)$ (Dibi et al., 2008) or $G=\pi D^{2} / 4$ (Ouedraogo et al., 2008), with $\mathrm{D}=$ diameter at $1.30 \mathrm{~m}$ from the ground. 


$$
-3781-
$$

\section{Statistical analysis}

Statistical tests were based on the variance between the fire regime and the defenses. The main factor was the effect of defencion on savannas subject to the fire regime. The Fisher (ANOVA) test was the best choice because it had satisfactory results. Variables taken into account were floristic diversity and density. We used $\mathrm{R}$ version 2.10.1 software. (Cornillon et al., 2010) and the level of significance of the results retained is 0.05 and 0.0001 depending on the case.

\section{Results}

\section{Floristic composition}

The analyzes performed relate to density $(\mathrm{N})$, relative density (DER), basal areas (G), occurrences, frequencies, relative dominance (DOR), importance value of species (IVI) and the importance value of families (VIF). The figure 5 below shows the Specific Wealth in SMD and SRF

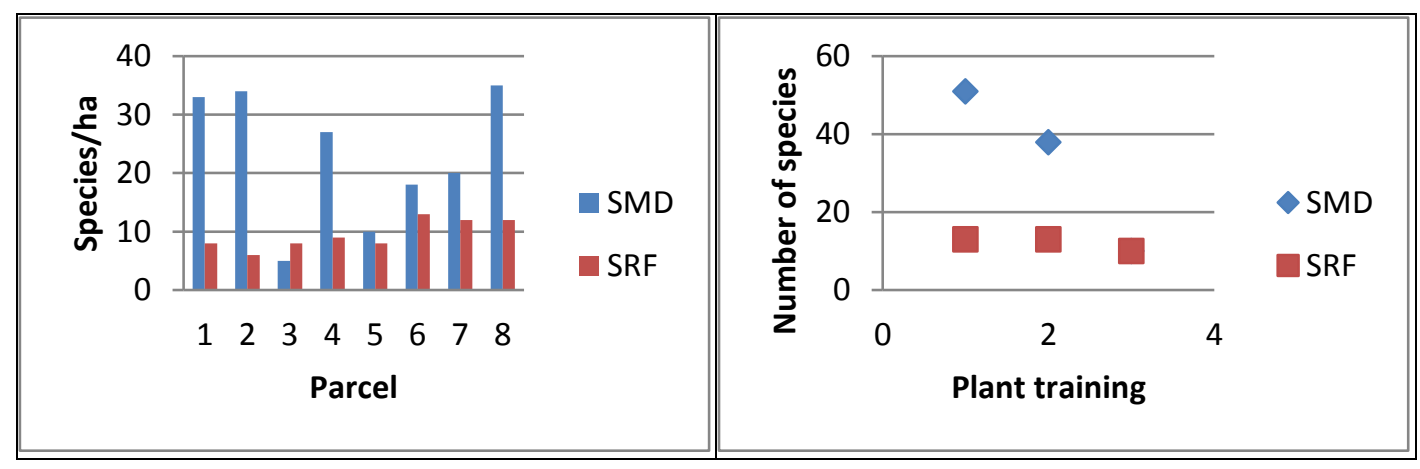

Figure 5. Specific Wealth in SMD and SRF

The following diagrams (Figure 6) present the results of analyzes based on species importance indices (IVI), family importance value indices (VIF) in the SMD and SRF, and relative dominance (DER) in sub-categories plots of the SMD.

The following table (Table 1) presents a summary of the different variables used for the analysis of the floristic composition and Table 2 the Synthesis of the regeneration in the savanna sub-plots placed in defense.

Table 1. Summary analysis of indices in plots

\begin{tabular}{c|c|c|c|c|c|c|c}
\hline Type & Variables & Oc. & FRR & DER & DOR & IVI & VIF \\
\hline \multirow{3}{*}{ SMD } & Average & 3.19 & 1.78 & 1.75 & 1.75 & 5.26 & 12.00 \\
& Stdev & 2.15 & 1.18 & 4.23 & 3.76 & 8.71 & 25.62 \\
& Variability (\%) & 67.34 & 66.40 & 241.02 & 214.20 & 165.44 & 213.47 \\
\hline \multirow{3}{*}{ SRF } & Average & 4.53 & 5.88 & 5.88 & 5.88 & 17.65 & 30.00 \\
& Stdev & 2.55 & 3.31 & 11.26 & 10.81 & 24.32 & 56.96 \\
& Variability (\%) & 56.35 & 56.35 & 191.46 & 183.82 & 137.80 & 189.86 \\
\hline
\end{tabular}

Oc = Occurrence; FRR = Relative Frequency; DER = Relative Density; DOR = Relative Dominance; IVI = Value of Significance Index; IVI = Family Importance Index 


$$
\text { - } 3782 \text { - }
$$

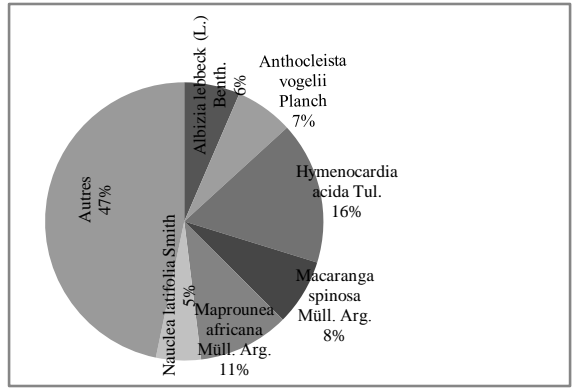

Diagram 1. Dominant Species / SMD

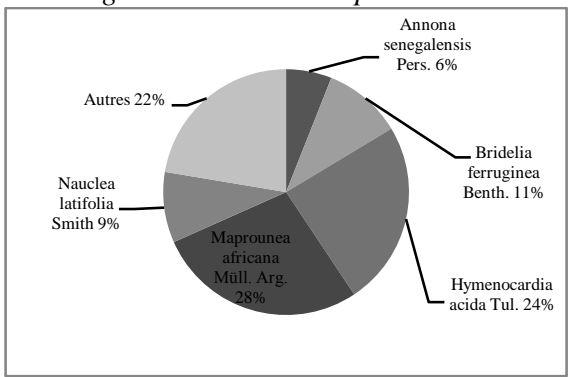

Diagram 3. Dominant species / SRF

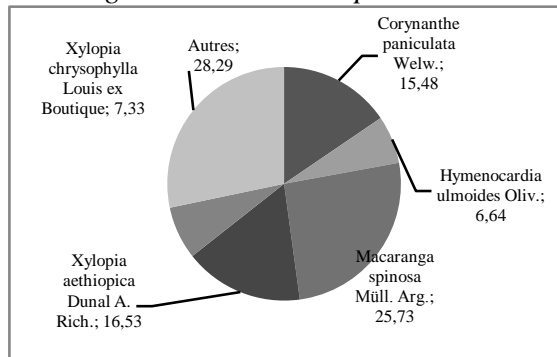

Diagram 5. Species and dominant families in the subplots

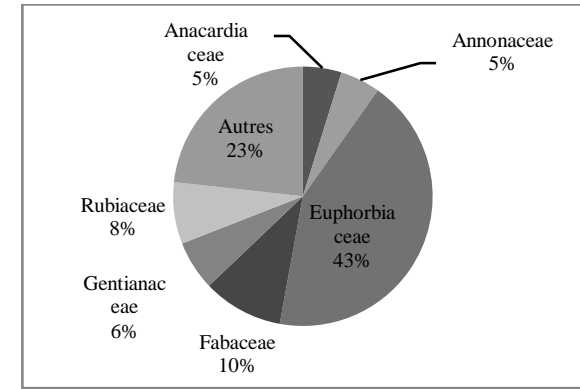

Diagram 2. Dominant Families / SMD

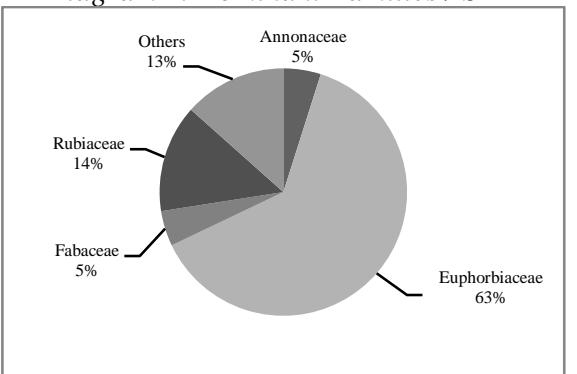

Diagram 4. Dominant families / SRF

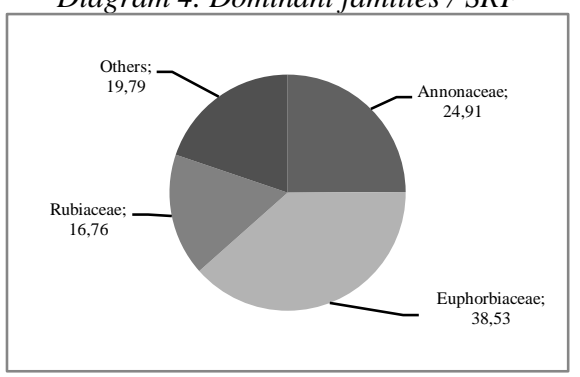

Diagram 6. Dominant families in the subplots

Figure 6. Percentage of dominant species and families in the two types of savannah (SMD and $S R F)$ as well as in the subplots

Table 2. Synthesis of the regeneration in the subplots of the savannah put in defense

\begin{tabular}{|c|c|c|c|c|c|}
\hline Number & Species & N.I & Oc. & FRR & DER \\
\hline 1 & Macaranga spinosa Müll. Arg. & 221 & 5 & 8,1 & 25,7 \\
\hline 2 & Xylopia aethiopica Dunal A. Rich. & 142 & 4 & 6,5 & 16,5 \\
\hline 3 & Corynanthe paniculata Welw. & 133 & 5 & 8,1 & 15,5 \\
\hline 4 & Xylopia chrysophylla Louis ex Boutique & 63 & 3 & 4,8 & 7,3 \\
\hline 5 & Hymenocardia ulmoides Oliv. & 57 & 4 & 6,5 & 6,6 \\
\hline 6 & Oncoba welwitschii Oliv. & 42 & 3 & 4,8 & 4,9 \\
\hline 7 & Anthocleita vogelii Planch & 32 & 4 & 6,5 & 3,7 \\
\hline 8 & Albizia adianthifolia (Schumach.) W. Wight & 30 & 3 & 4,8 & 3,5 \\
\hline 9 & Symphonia globulifera L. f. & 30 & 1 & 1,6 & 3,5 \\
\hline 10 & Hymenocardia acida Tul. & 25 & 3 & 4,8 & 2,9 \\
\hline 11 & Croton sylvaticus Hochst. ex Krauss & 21 & 3 & 4,8 & 2,4 \\
\hline 12 & Vernonia conferta Benth. & 11 & 2 & 3,2 & 1,3 \\
\hline 13 & Heinsia pulchella (G. Don) K. Schum. & 10 & 4 & 6,5 & 1,2 \\
\hline 14 & Xylopia hypolampra Mildbr. & 9 & 3 & 4,8 & 1,0 \\
\hline 15 & Tetrorchidium didymonstemon (Baill) Pax et K. & 7 & 1 & 1,6 & 0,8 \\
\hline 16 & Holarrhena congolensis Stapf & 5 & 1 & 1,6 & 0,6 \\
\hline 17 & Albizia lebbeck (L.) Benth. & 4 & 2 & 3,2 & 0,5 \\
\hline 18 & Barteria nigritiana Hook. f. & 4 & 2 & 3,2 & 0,5 \\
\hline 19 & Hylodendron gabunense Taub. & 3 & 1 & 1,6 & 0,3 \\
\hline 20 & Zanthoxylum gilletii (De Wild.) P.G.Waterman & 3 & 2 & 3,2 & 0,3 \\
\hline 21 & Markhamia sessilis Sprague & 2 & 1 & 1,6 & 0,2 \\
\hline 22 & Albizia ferruginea (Guill. \& Perr.) Benth. & 1 & 1 & 1,6 & 0,1 \\
\hline 23 & Canthium oddonii (De Wild.) C. Evrard & 1 & 1 & 1,6 & 0,1 \\
\hline 24 & Dacryodes buettneri (Engl.) H. J. Lam & 1 & 1 & 1,6 & 0,1 \\
\hline 25 & Millettia versicolor Welw. ex Baker & 1 & 1 & 1,6 & 0,1 \\
\hline 26 & Trichilia gilgiana Harms & 1 & 1 & 1,6 & 0,1 \\
\hline
\end{tabular}

Oc $=$ Occurrence FRR = Relative Frequency; DER = Relative Density; NI = Number of individuals 


$$
-3783-
$$

\section{Density of stand of the plots in the savannah put in defenses and the savannah under fire regime}

This density is presented in Figure 7 for the two types of savannah, namely SMD and SRF.
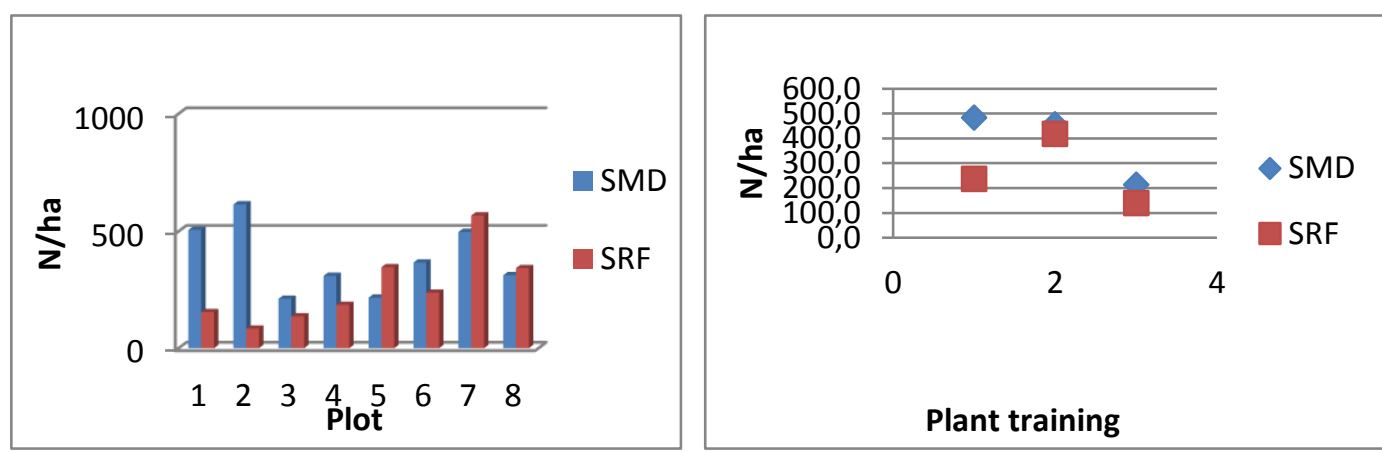

Figure 7. Density in the $S M D \& S R F$

Structure of the planted flora in the savannah set in defense (SMD) and savannah under fire regime $(S R F)$

The figures from 8 to 13 show the growth of trees based on their circumferences and heights divided into classes of $10 \mathrm{~cm}$ and $5 \mathrm{~m}$ respectively. The figures 8 and 9 show the general horizontal and vertical tree structure in SMD and SRF as well as the basal area in the two savannah landscapes. Figures 10 and 11 show the horizontal and vertical structure of two characteristic species: M. africana Müll. Arg. and H. acida Tul. in SMD and SRF.
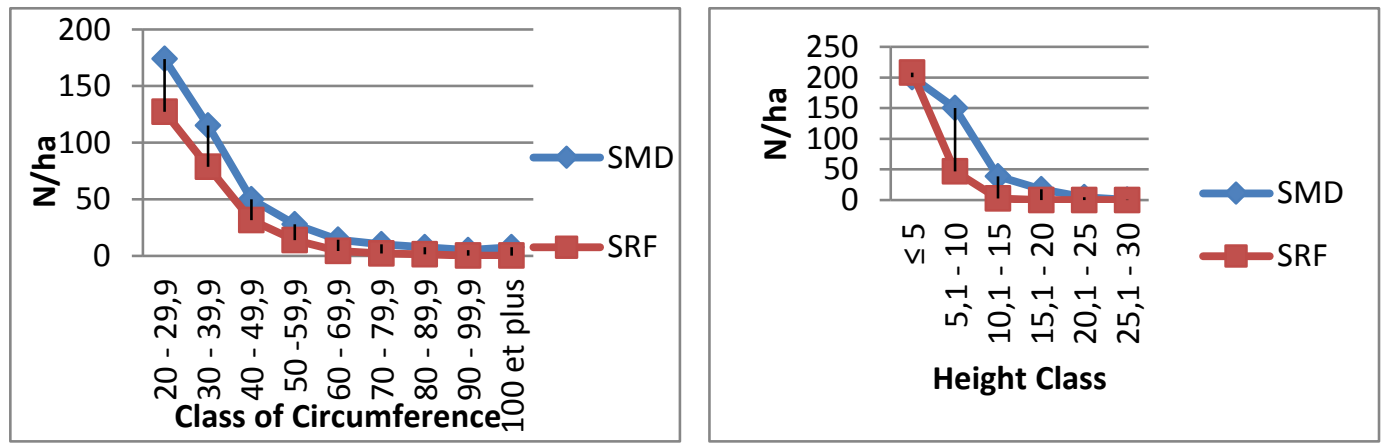

Figure 8. Horizontal and vertical tree structure in SMD and SRF
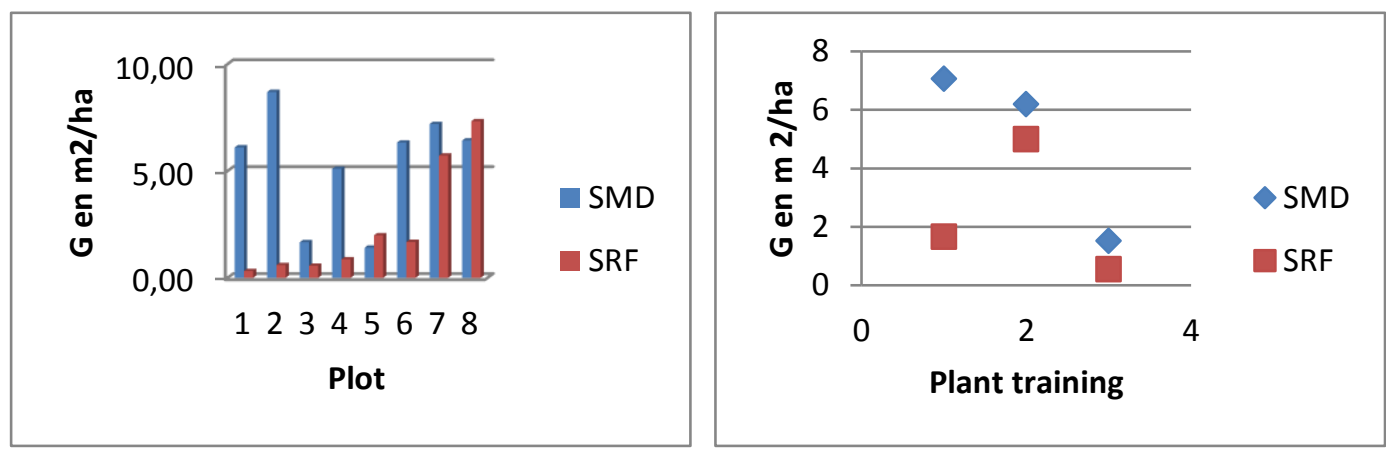

Figure 9. Basal area in $S M D$ and $S R F$ 

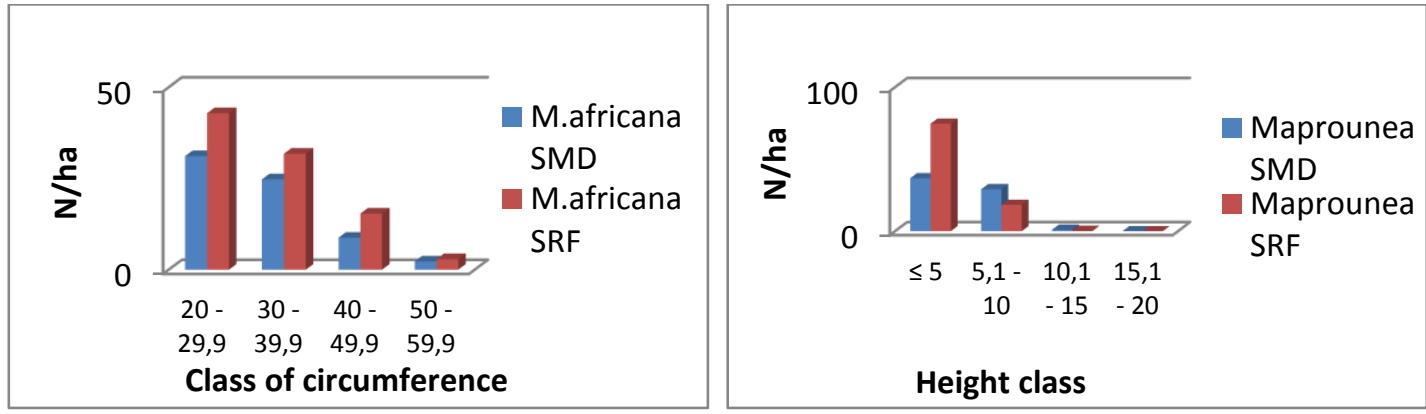

Figure 10. Horizontal and vertical structure of M. africana Müll. Arg. in the SMD and the SRF
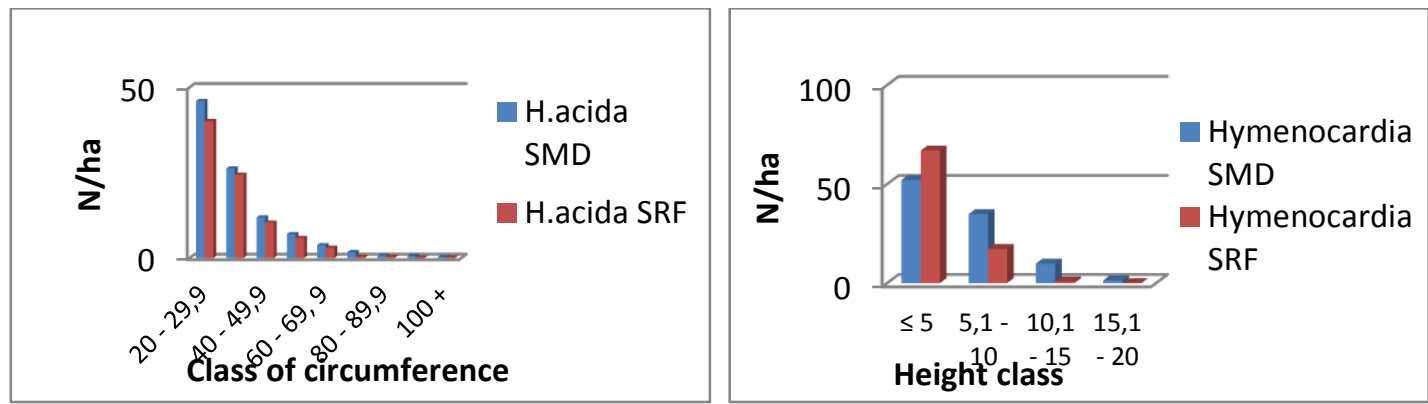

Figure 11. Horizontal and vertical structure of H. acida Tul. in SMD and SRF

Figures 12 and 13 show the horizontal and vertical structure of a pre-forest species (M. spinosa Müll. Arg.) in the SMD as well as the horizontal and vertical structure of a forest species (X. aethiopica Dunal A. Rich.) in the SMD and the SRF.
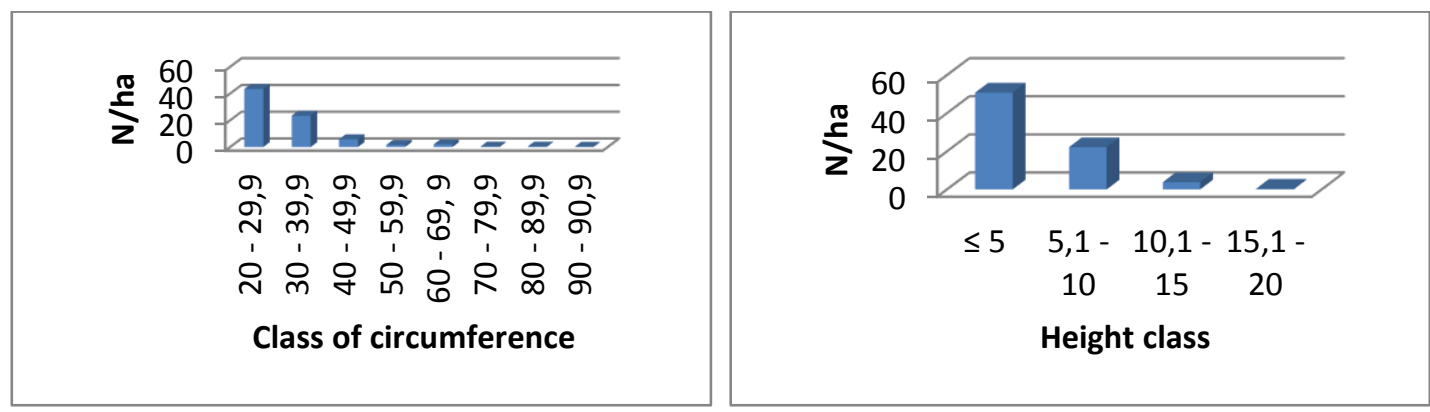

Figure 12. Horizontal and vertical structure of M. spinosa Müll. Arg. in the SMD
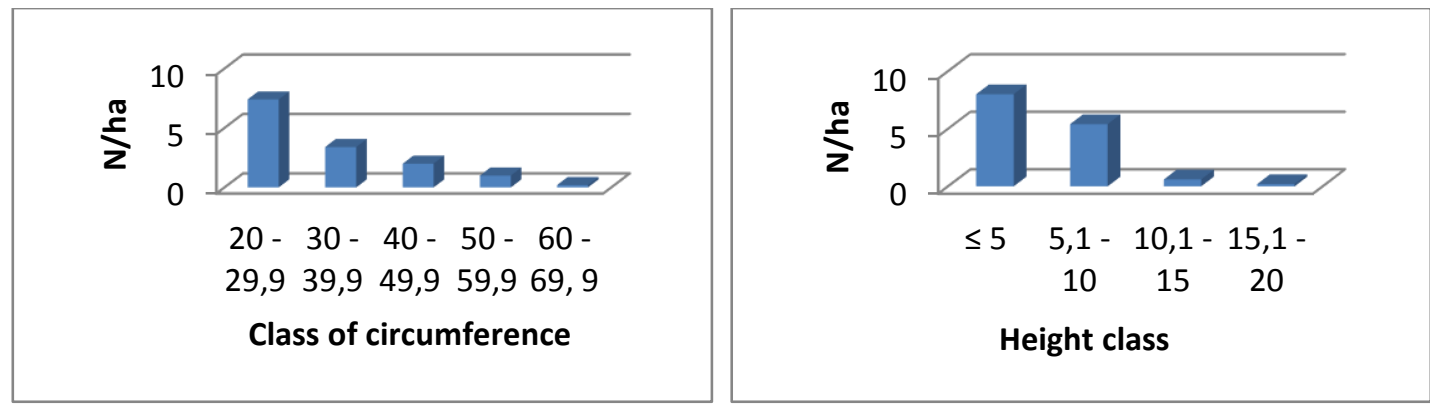

Figure 13. Horizontal and vertical structure of X. aethiopica Dunal A. Rich. In the SMD and the SRF 


\section{Statistical analysis}

Statistical analysis presents the Specific Richness (Figure 14), the Density (Figure 15), as well as the basal area (Figure 16) for the SMD and SRF.

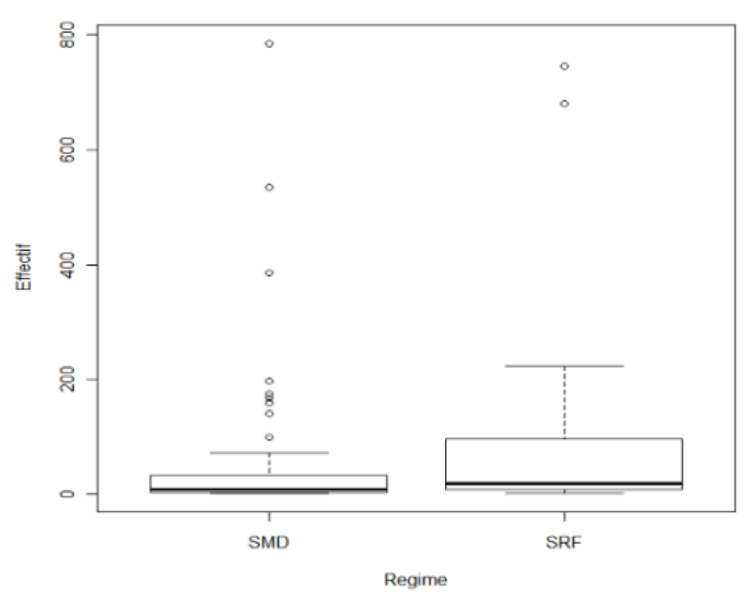

Figure 14. Dispersion of the numbers of woody species in two regimes (SMD and SRF) $(F=2.04, P>0.05)$

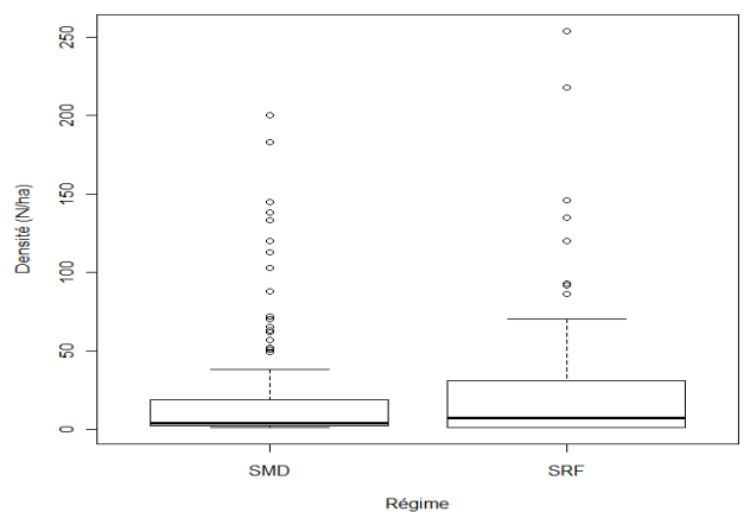

Figure 15. Density dispersion of woody species from two regimes (SMD and $S R F)$. $(F=3.05$, $P>0.05)$

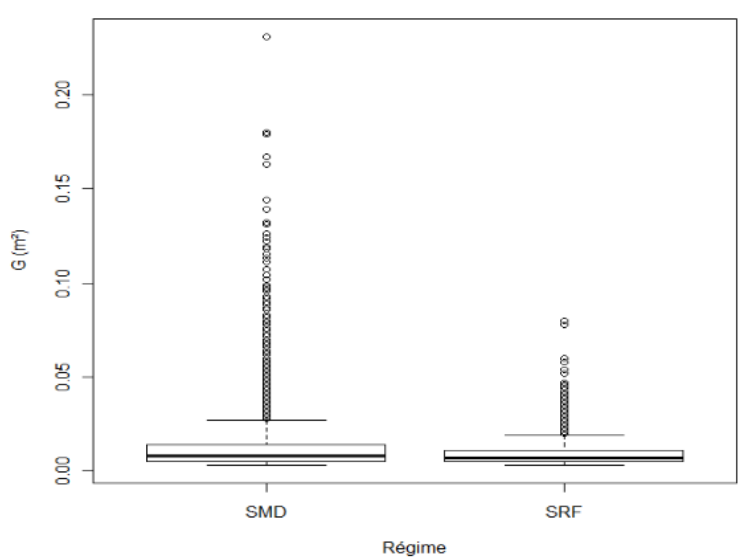

Figure 16. Basal area value dispersion for the two regimes $(S M D$ and $S R F) .(F=108.53$,

$$
P<0.0001
$$




\section{Discussion}

\section{Floristic diversity}

The results obtained in this work show that SMD includes the highest number of species (61), genera (50) and families (25). SRF has a low diversity: 17 species, 16 genera and 10 families. The overall average species is 10 species / ha for SRF and 23 species / ha for SMD. The IVI analysis shows that Hymenocardia acida Tul., Maprounea africana Müll. Arg., Macaranga spinosa Müll. Arg., Anthocleista vogelii Planch, Albizia lebbeck (L.) Benth., Nauclea latifolia Smith., Lannea welwitschii (Hiern) Engl. and Bridelia ferruginea Benth. are species with a higher relative density in the savannah protected; better distributed in the SMD (50\%) and are highly important depending on the basal area they occupy (Figure 6 / Diagram 1).

The analysis shows that the families Euphorbiaceae, Fabaceae and Rubiaceae, are the most important families (Figure 6 / Diagram 2). In the work of Dibi et al. (2008), carried out in forest-savanna contact zone, these families are among the most important families. In the SRF, Maprounea africana Müll. Arg., Hymenocardia acida Tul., Bridelia ferruginea Benth., Nauclea latifolia Smith, and Annona senegalensis Pers., Are species with higher DER. Likewise, these species are best distributed and are highly important depending on the basal area they occupy (Figure 6 / Diagram 3).

According to the work of Devred (1956), these species are among the typical species of the Bas-Congo savannah, adapted to fires and difficult conditions. Such vegetation can be described as a pyrophyte because its destruction by fire is followed by a reconstitution phenomenon, (although slow because of edaphic conditions), but without any profound change in the type of vegetation or flora (Jaffré et al., 1998). This reflects the ability of the ecological system to respond to a disturbance by returning to the stage before it. In SRF Euphorbiaceae, Rubiaceae and Annonaceae are the most important families (Figure 6 / Diagram 4). Note in the SMD that Hymenocardia acida Tul. and Maprounea africana Müll. Arg. are dominant, their proportion remains low compared to the SRF, likewise for the Euphorbiaceae family. In the SRF Maprounea africana Müll. Arg. is more represented than Hymenocardia acida Tul; Maprounea africana Müll. Arg. withstands fire better because of its thick bark.

The sub-plots were dominated inside of the SRF and SMD by the species like: Macaranga spinosa Mull, Xylopia aethiopica Dunal, Corynanthe paniculata Welwich, Xylopia chrysophylla Louis, Hymenocardia ulmoides Oliv; as well as families of Euphorbiaceae, Anonaceae, Rubiaceae and others (Figure 6 / Diagram 5). The diversity is low in plots 3 and 5 (SMD), this is related to the nature of the substrate on which they are based. The substrate can play an important role in the non-installation of species that can not withstand these harsh conditions even though the savannah is put in defense. On poor soil, the work of Louppe et al. (1995) shows that in plots protected from fire there are 6 times fewer species, 32 times fewer individuals and a reduced basal area of nine tenths.

Parcel 6 in the SRF (Border), although subject to fire, is based on low-lying humus soil that provides favorable conditions for the establishment of other species. Plots 7 and 8 of the SRF are in a kraal and are used as pasture. These are covered by an early fire to allow livestock to have green grass during the dry season. A well-conducted early fire eliminates the risk of a second fire during the same dry season. Jacquin (2010) states that, at the intra-annual scale, early fires in the dry season favor the development of woody species by disadvantaging herbaceous species. 
By analyzing the results of the parcel-by-plot inventory, it is noted that the border in the SMD, presents a highly evolved floristic composition with a high recovery rate (Figure 7). The presence in the edges of SMD of pre-forest and forest fallow species (Trema orientalis (L.) Blume, Tetrorchidium didymonstemon (Baill) Pax and K., Albizia gummifera (JF Gmel.) CA Sm., Oncoba welwitschii Oliv, Harungana madagascariensis Lam. Ex Poir, etc., and forest species (Eriocoelum microspermum Radlk, ex De Wild, Deinbolia acuminata Exell, Microdesmis puberula Hook, ex Planch, Musanga cecropioides R. Br. Myrianthus arboreus P. Beauv., Pseudospondias microcarpa (A. Rich.) Engl., Etc.), testifies to the positive effect of the setting in defense and a proof that a protected savanna, in contact with the forest can evolve towards a climactic ecosystem.

Louppe et al. (2008), states that Albizia gummifera (J. F. Gmel.) C. A. Sm., Occurs in the savannahs near the forest. Youta (1998) estimates that the genus Albizia is present in clearings and windfall; their presence outside these openings testifies to the existence of old clearing without which they could not grow normally. The setting in defense allowed certain groves to maintain, and even to extend, which would not be possible under the conditions of the fires. Jacquin (2010) states that the absence of fire pressures would promote forest regeneration.

The averages of the indices in Table 1 give higher values in the SRF than in the SMD, which is explained by the low specific diversity observed in the SRF compared to the SMD. The more a stand is diversified; the averages of these indices are small. It is also noted that there is a great heterogeneity between the different stands in both SMD and SRF because the variability is far greater than $15 \%$ (Table 1). This shows that after 6 years of protection against fire, species of savannas adapted to fire and difficult conditions continue to dominate in the floristic composition of the SMD and the SRF. Statistically, there is no difference between SMD and SRF $(\mathrm{F}=2.04, \mathrm{P}>0.05)$ (Figure 14).

\section{Density of stands}

Statistically, there is no difference in density between SMD and SRF ( F = 3.05, $\mathrm{P}>0.05$ ) (Figure 15). Numerically, the SMD gives a higher result (403.88 ind./ha on average) than that of the SRF (256.38 ind./ha on average). The results of a study conducted by FAO in the Lubumbashi region (available at http: //www.fao.org /docrep /T0748F/t0748f07.htm) show that after 6 years of establishment in a forest clear, the density of the plots can double. The figures obtained after inventory for our study in the SMD (403 ind./ha on average) are generally satisfactory because they are close to the figures obtained by the FAO in Lubumbashi, by Dibi et al. (2008) in the PNM in the forest zone and by Bouko et al. (2007) in Benin. These results are superior to those obtained by Dibi et al. (2008) in the PNM in savanna (203 and 56 plants / ha). The results obtained in shrubby savanna are low compared to those obtained by Devineau (1997) in Burkina Faso where the density is 1500 plants / ha.

The work of Louppe et al. (1995) shows that the number of surviving species, after 58 years of fire, is only 20 for 214 individuals per hectare. The work of Monnier (1990) shows that after 30 years of defencion savannah has 21,780 individuals against 13,227 in that which was subject to early fire and only 4,251 in that subject to late fires. 


\section{Stand structure}

A good analysis of stand dynamics takes into account two variables that are important: the vertical and horizontal structure (Mitja, 1992). Mitja (1992) argues that the vertical structure offers, among other things, an interest in providing an indicator of site richness and that the horizontal structure accounts for the distribution of individuals in the horizontal plane.

The analysis of Figures 8 and 10-13, dealing with the distribution of stems by circumference class and height shows a decrease in the number of individuals as the circumference and height increase. Looking at Figure 8, we note that the overall structure of the stand is not a decreasing asymptote or an inverted $\mathrm{J}$ as it might be the case for a tropical dense rain forest (Dibi et al. 2008), but rather tends towards a decreasing distribution in L (Bouko et al. 2007). These could be growing populations because of the very high numbers of small trees and a very small number of trees with large circumferences. But some characteristic species of individual savannas, including Hymenocardia acida Tul (Fig. 11), offer an asymptotic structure.

There is also a fairly large gap between the SMD and the SRF curve for both circumference and height. The SRF curve drops rapidly to zero a little further than that of the SMD and shows that in the SRF there is a very small number of trees of great circumference following the action of the fire. The work of Dupuy et al. (1997) shows that there are more individuals in the 1st class of diameter in the exploited and burnt forest.

Statistically, analyzing the basal areas in the SMD and the SRF we note that the difference is very significant $(\mathrm{F}=108.53, \mathrm{P}<0.0001)$. The box plot in Figure 16 shows the interval in which $50 \%$ of the basal areas are grouped and the thick bar inside the box indicates the mean; the bar below indicates the minimum basal area and the bar above the box indicates the maximum basal area. The presence of individuals appearing above the upper mustache is often considered to be aberrant (Cornillon, 2010). For this study these individuals are mostly individuals of the edge whose $G$ values deviate from the general average and this is a proof of the strong variability that characterizes all stands.

Figure 9 shows that SMD plots have higher basal areas than SRF plots. Similarly, in plant formations, the averages are higher in SMD than in SRF. In the SRF there is an increase for parcels 7 and 8, which are located in a kraal covered by an early fire. The results obtained in the SMD are low compared to those obtained by Dibi et al. (2008) in the forest-oriented PNM, but they are satisfactory compared with those obtained by Bouko et al. (2007) in Benin in the forest, wooded savannah, fallows and fields. The results obtained by Devineau (1997) in shrubby savanna are about five times higher than those obtained by our study in the SMD.

The vertical structure (Figure 11), which is the distribution of individuals by height class, shows that the SMD is higher than the SRF. It can also be noted that the fire often lit at critical periods (end of the dry season) does not allow ligneous trees to develop important ports (heights and trunk diameters). This difference in the vertical structure of SMD and SRF is well numerically perceptible at the level of stem densities (Figure 9). This difference is perceptible statistically in the basal areas (Figure 16). The structure of species $H$. acida Tul and M. africana Müll. Arg. which are dominant in the SMD and the SRF, shows that the most represented individuals are in the circumference class of 20 and 30, most of which do not exceed $5 \mathrm{~m}$ high (Figures 10 and 11). This confirms the work of Devred (1956) whose results show that these species are pyrophytes and adapted to extreme conditions. 
The results showed that $M$. africana Müll. Arg is much more adapted to fires than H. acida Tul, attributable to its thick bark. Both species have good regeneration in both SMD but not in SRF. These assertions are made subject as long as the work of the dendrochronology does not confirm them, because we estimate that in the difficult conditions of the sites, the size of the trees can not necessarily translate the age of the trees. M. spinosa Müll. Arg. (Figure 12) which is a pre-forest species exhibits good behavior in SMD. Similarly, X. aethiopica Dunal A. Rich (Figure 13), which is a secondary forest species, also exhibits good behavior; blatant sign of the reforestation process in the SMD.

\section{Regeneration}

The purpose of this inventory was to analyze the effective regeneration of species (Mitja, 1992), the effects of bush fires and the benefits of defensive management, but also to predict the future floristic physiognomy. In the FRS, subplot inventory results indicate the complete absence of young individuals, even in plot 3 and 5 of the SMD. Clément (1982) states that in a bushfire savannah the original tree vegetation does not recover. Louppe et al. (1995) argue that adult trees of fire-resistant pyrophile species can continue to grow but fail to regenerate and that young subjects, booms and stumps are often destroyed by fire. They claim that some saplings can survive, perhaps during very rainy years that limit the intensity of fire. The low rainfall in the area of our study makes this regeneration unlikely after fire.

In the SMD, the results obtained (Table 2) in general are encouraging, although some concerns remain on the northern part of the savanna (plots 3 and 5), a situation attributed to the substrate. The hygrophilic nature of most of the savannah patches put in defense (consequence of the setting in defense) is favorable with the germination of very many seedlings. The frequencies in the sub-plots of SMD show that there is a strong presence of species that are not strongly represented in the adult state. The work of Mitja (1992) confirms these results.

This analysis allows us to predict a significant change in the floristic composition of the tree and tree layer if the fire protection of this savannah continues. The FAO report on the study of open woodlands around Lubumbashi shows that defensibility allows for considerable enrichment, especially in young people. A closer analysis shows that, in parallel with the increase in the number of individuals, there is a marked improvement in the floristic composition. The most savanna species are becoming scarce over the years, as are the indicators of degraded situations (fire or arid and poor soil). The Euphorbiaceae family remains the most dominant family as is the case in the SMD and SRF plots (Figures 7, 9 and 11).

\section{Similarity between the savannah protected and plots under fire}

The value of the Sorensen similarity coefficient between SMD and SRF is less than $50 \%$ (43.24), indicating that at the level of the floristic composition, these two entities are different from each other (Dibi et al., 2008). By analyzing this parcel ratio per parcel, the parcels of the SMD have a strong similarity between them.

Comparing the large plant formations (edge, tree savannah and shrub savannah) of the SMD, there is a strong similarity between the edges of the edge and those of the wooded savanna (71.91), while between the plots of the edge and those of the shrub savannah the similarity is less (32.78). The patches of savannah and shrub savannah also have a low similarity (41.66). This same comparison shows that there is a strong 
similarity between the plant formations of the SRF. The similarity is weak between the plant formations (edge and savanna tree) of the SMD and the SRF, but it remains high between the bush savannah of the SMD and the SRF (edge, savannah and savannah shrub).

The work of Dibi et al. (2008) has shown that the different savannah formations have a similarity coefficient of less than $50 \%$ and are therefore floristically different. In the SMD, plots P3 and P5 are those which do not undergo a spectacular evolution in terms of species that the rest of the savannah plots put in defenses. The soil (ferruginous gravel, quartz pebbles) and the presence of boulders from bedrock spoilage in these patches may be the cause.

Nébié (2005) states that these harmful aspects inherent to the soil represent an obstacle to the normal development of the vegetation, since the roots have only a small thickness of exploitable soil. Soils in these areas are generally shallow (Doucet, 2003), and characterized by downward leaching of clay downward and infiltration of rainwater (Nébié, 2005). Their structure is massive, frequently compact, indurated on the surface (Devineau, 1997), their chemical wealth is low: deficiency in lime and magnesium. Devineau (1997) considers that if such soil has never been cultivated, it must be considered as a stage of degradation of the pyroclimax under the effect of grazing. But in the case of our study it is rather a highly anthropized savanna.

\section{Conclusion}

Work in the SMD and SRF identified 63 plant species across all SMD plots and 17 species in SRF. These species are divided into 51 genera and 26 families. The dominant species are $H$. acida Tul and $M$. africana Müll. Arg, and the dominant families are: Euphorbiaceae, Fabaceae and Rubiaceae. The overall average of species is 10 species per ha for SRF and 23 species per ha for SMD. The results of this study showed that SMD is more diversified than SRF but this diversity is still very low compared to the diversity observed in forest areas. Stand structure indicates that SMD has a larger basal area than SRF. Overall, trees in SMD are taller than SRF trees.

In each case study (SMD and SRF), the community or similarity coefficient is very high between plots of the same case, but comparing these two treatments the coefficient of similarity is low (43.23). Which means that at the floristic level the SMD and different from the SRF.

The results of this work showed that 6 years after the setting in defense, the vegetation of the savannah is in full evolution and that the putting in defense of the savannas constitutes one of the effective means to favor the forest regeneration around Luki. These results show that the reforestation process started well before the defensive period, and confirm that the protection of this savannah allowed this savannah to reach the current structure. These preliminary results contribute to understanding the impact of savanna conversions on climate change. This will enable decision-making in the sustainable management of savannahs and the protection of the environment.

As a recommendation related to this study we suggest the following:

A. To researchers:

- Always characterize the savannas to be defended and make a floristic inventory in the first year of disposal, in case the experiment should be duplicated. This would make it possible to follow the normal evolution of the savannah put in defenses year by year. 
- Conduct analytical studies of soils in different plant formations and / or plots of the SMD, to further explain the flora they display.

- Monitor the plots and subplots installed in the SMD annually to understand the evolution of their composition and structure and determine annual increments.

- Integrate the work of dendrochronology to estimate the age of the SMD stands, this work would make it possible to determine the speed of the progression of the forest.

- Install plots at the savanna edge interface to assess the rate of savannah colonization by edge features.

- Continue to support local populations by multiplying projects and incomegenerating activities promoting development in order to free them from the total dependence of forest products.

- Increase awareness

B. To the local people surrounding the savannah of Manzonzi:

- Continue to protect the protected savannah in order to safeguard its assets.

\section{REFERENCES}

[1] Arruda, D. M., Schaefer, C. E. G. R., Correa, G. R., Rodrigues, P. M. S., Duque-Brasil, R., Ferreira-JR, W., Oliveira-Filho, A. T. (2015): Landforms and soil attributes determines the vegetation structure in the Brazilian semiarid. - Folia Geobot 50: 175-184.

[2] Baudena, M., Dekker, S. C., van Bodegom, P. M., Cuesta, B., Higgins, S. I., Lehsten, V., Reick, C. H., Rietkerk, M., Scheiter, S., Yin, Z., Zavala, M. A., Brovkin, V. (2015): Forests, savannas, and grasslands: bridging the knowledge gap between ecology and Dynamic Global Vegetation Models. - Biogeosciences 12: 1833-1848.

[3] Bouko, B. S., Sinsin, B., Soule, B. G. (2007): Effects of land-use dynamics on the structure and floristic diversity of open forests and savannas in Benin. - Tropicultura 25(4): 221-227.

[4] Burrows, N. D. (2008): Linking fire ecology and fire management in South - West Australian forest landscapes. - Forest ecology and management 255: 2394-2406.

[5] Clément, J. (1982): Estimation of volumes and productivity of mixed tropical forest and grass formations. Data on french African countries in northern Ecuador and recommendations for conducting new studies. - Forestry and Forests of the Tropics magazine 198(4), $24 \mathrm{p}$.

[6] Cornillon, P. A., Guyader, A., Husson, F., Jegou, N., Josse, J., Kloareg, M., Matzner, L. E., Rouviere, L. (2010): Statistics with R. $2^{\text {nd }}$ augmented edition. - Rennes University Presses, French statistical society, $274 \mathrm{p}$.

[7] Dale, M. R. T. (1999): Spatial Pattern Analysis in Plant Ecology. - Cambridge, UK. Cambridge University Press.

[8] De Foresta, H. (1990): Origin and evolution of intramayambian savannahs (D.R Congo). II. Contributions of forest botany. - Quaternary Landscapes of Central Atlantic Africa. Available at: http://horizon.documentation.ird.fr/exl-doc/pleins_textes/divers11-10 134796.pdf.

[9] Deklerck, V., De Mil, T., Ilondea, B. A., Nsenga, L., De Caluwe, C., Van den Bulcke, J., Van Acker, J., Beeckman, H., Hubau, W. (2019): Rate of forest recovery after fire exclusion on anthropogenic savannas in the Democratic Republic of Congo. - Biological Conservation 233: 118-130.

[10] Devineau, J. L., Lecordier, C., Vuattoux, R. (1984): Evolution of the specific diversity of the woody stand in a pre-forest succession of colonization of a savannah protected from 
fire (Lamto, Ivory Coast). - Candollea 39(1): 103-134. Available at: http://hal.archivesouvertes.fr/docs/00/43/49/47/PDF/Devineau_et_al_1984.pdf.

[11] Devineau, J. L. (1997): Seasonal evolution and rate of increase of basal areas of ligneous trees in some Sudanese savannah stands in western Burkina Faso. - Ecology t, 28(3): 217-232.

[12] Devred, R. (1956): The grassy savannas of Mvuazi region (Bas Congo). - INEAC publications, Scientific Series No. 65, 122 p.

[13] Dibi, N. H., Yao, C. Y. A., Kouakou, N. E., Kone, M., Yao, S. C. (2008): Analysis of the floristic diversity of the Marahoué National Park, Central West of Côte d'Ivoire. - Africa science 4(3): 552-579.

[14] Doucet, J. L. (2003): The delicate alliance of forest management and biodiversity in the forests of central Gabon. - Original dissertation submitted for the degree of Doctor of Agricultural Sciences and Biological Engineering. University Faculty of Agricultural Sciences, Gembloux, Belgium, 390 p.

[15] Duarte, L. Da S., Dos-Santos, M. M. G., Hartz, S. M., Pillar, V. D. (2006): Role of nurse plants in Araucaria Forest expansion over grassland in south Brazil. - Austral Ecology 31(4): 520-528.

[16] Dupuy, B., Bertault, J. G., Doumbia, F., Diahuissie, A., Brevet, R., Miezan, K. (1997): Natural regeneration in dense Ivorian forest production. - CIRAD-Forêt. Tropical forests and forests 24(4): 25-38.

[17] Favier, C., Namur, C. D., Dubois, M. A. (2004): Forest progression modes in coastal Congo, Central Atlantic Africa. - Journal of Biogeography 31: 1445-1461.

[18] Favrichon, V., Gourlet-Fleury, S., Barhen, A., Dessart, H. (1998): Permanent plots in dense rainforest. Element for a data analysis methodology. - CIRAD - Forêt Campus International de Baillarquet. FORAFRI 1998 series document 14, 30432 Montpellier Cedex 1, France, 67 p.

[19] Guenon, R. (2010): Vulnerability of Mediterranean soils to recurrent fires and restoration of their chemical and microbiological qualities by the addition of composts. - Thesis to obtain the degree of doctor of the university Paul Cézanne. Faculty of Science and Technology, 248 p. http://www.fao.org/docrep/T0748F/t0748f07.htm.

[20] Higgins, S. I., Bond, W. J., Trollope, W. S. W. (2000): Fire, resprouting and variability: a recipe for grass-tree coexistence in savanna. - J. Ecol. 88: 213-229.

[21] House, J. I., Archer, S., Breshears, D. D., Scholes, R. J. (2003): Conundrums in mixed woody-herbaceous plant systems. - J. Biogeogr. 30: 1763-1777.

[22] Hutchinson, G. E. (1961): The paradox of the plankton. - Am. Nat. 95: 137-145.

[23] Jacquin, A. (2010): Dynamics of savanna vegetation in relation to the use of fires in Madagascar. Time series analysis of remote sensing images. - Thesis in order to obtain the doctorate of the University of Toulouse, $146 \mathrm{p}$.

[24] Jaffré, T., Rigault, F., Dagostini, G. (1998): Impact of bush fires on the ligno-herbaceous maquis of the ultramafic rocks of New Caledonia. - FAO, AGRIS, Adansonia 20(1).

[25] Kapa, B., Nkiama, M., Malele, M., Ritvisay, M. (1987): Development of the Luki Biosphere Reserve. - SPIAF, $67 \mathrm{p}$.

[26] Kent, M., Coker, P. (1992): Vegetation Description and Ananlysis: A Practical Approach. - Boca Raton: CRC Press.

[27] Louppe, D., N'klo, O., Alasanne, C. (1995): Effect of bush fires on vegetation. - Tropical wood and forest 245(3), $16 \mathrm{p}$.

[28] Louppe, D., Oteng - Amoako, A. A., Brink, M., Lemmens, R. H. M. J., Oyen, L. P. A., Cobbinah, J. H. (2008): Plant Resources of Tropical Africa 7(1): timbers 1. - PROTA Foundation / Blachhuys publishers / CTA. Wageningen, the Netherlands, 785 p.

[29] Lubalega, T. (2016): Évolution naturelle des savanes mises en défens à Ibivillage, sur le plateau des Bateke, en République Démocratique du Congo. - Thèse en cotutelle Université Laval/ Québec, Canada/ Philosophiae doctor (Ph.D.). 
[30] Lubini, A. (1997): Vegetation of the Luki Biosphere Reserve in Mayombe (Zaire). Opera botanica Belgica 10. National Botanical Garden of Belgium, Meise, 155 p.

[31] Manlay, R., Peltier, R., N'toupka, M., Gautier, D. (2002): Assessment of the tree resources of a Sudanese savanna village in North Cameroon for sustainable management. - In: Jamin, J. Y., Seiny Boukar, L., Floret, C. (eds.). African savannahs: changing spaces, actors facing new challenges. Proceedings of the symposium, May 2002, Garoua, Cameroon. Prasac, N'Djamena, Chad - CIRAD, Montpellier, France, 17 p.

[32] Menaut, J. C., Lepage, M., Abbadie, L. (1995): Savannas, woodlands and dry forests in Africa. - In: Bullock, S. H., Mooney, H. A., Medina, E. E. (eds.) Seasonally dry tropical forests. Cambridge University Press. Cambridge, England, 64-92 pp.

[33] Mitja, D. (1992): Influence of shifting cultivation on wet savannah vegetation in Côte d'Ivoire (Booro - Borotou - Touba). - ORSTOM, Paris, 269 p.

[34] Monnier, Y. (1968): Dust and ash. Landscapes, dynamic plant formations of societies in West Africa. - Ministry of Cooperation and Development / ACCT, Paris, 264 p.

[35] Mueller-Dombois, L. D., Ellenberg, E. (1974): Aims and Methods of Vegetation Ecology. - New York: John Wiley and Sons.

[36] Nebie, O. (2005): Settlement Experience and Development Strategies in the Nakambe Valley Burkina Faso. - Thesis presented at the Faculty of Arts and Humanities of the University of Neuchâtel to obtain the degree of doctor in human sciences. University of Neuchâtel Faculty of Arts and Humanities, 246 p.

[37] Ouedraogo, O., Thiombiano, A., Hahn-Hadjali, K., Guinko, S. (2008): Diversity and structure of woody groups in Arly National Park (Eastern Burkina Faso). - Flora and Vegetatio Sudano-Sambesica 11: 5-16.

[38] Peña-Claros, M., Poorter, L., Alarcón, A., Blate, G., Choque, U., Fredericksen, T. S., Justiniano, M. J., Leano, C., Licona, J. C., Pariona, W., Putz, F. E., Quevedo, L., Toledo, M. (2012): Soil effects on forest structure and diversity in a moist and a dry tropical forest. - Biotropica 44: 276-83.

[39] Quinif, Y. (1986): Genesis of karts with turns in intertropical countries the example of Bas - Zaire. - Annale of the Geological Society of Belgium 109: 515-527.

[40] Rodrigues, P. M. S., Gonçalves, C. E., Schaefer, R., de Oliveira Silva, J., Gomes, W., Júnior, F., Santos, R., Neri, A. V. (2016): The influence of soil on vegetation structure and plant diversity in different tropical savannic and forest habitats. - Journal of Plant Ecology 11(2): 226-236.

[41] Rondeux, J. (1993): The measurement of trees and forest stands. - 1st edition, Gembloux, Belgium: Agronomical Press of Gembloux, $522 \mathrm{p}$.

[42] Sankaran, M., Ratnam, J., Hanan, N. P. (2004): Tree-grass coexistence in savannas revisited - insights from an examination of assumptions and mechanisms invoked in existing models. - Ecol. Lett. 7: 480-490.

[43] Savadogo, P., Tigabu, M., Sawadogo, L., Odén, P. C. (2007): Woody species composition, structure and diversity of vegetation patches of a Sudanian savanna in Burkina Faso. - Bois et Foréts des Tropiques 294(4).

[44] Scholes, R. J., Walker, B. H. (1993): An African Savanna: Synthesis of the Nylsvley Study. - Cambridge University Press, Cambridge, UK.

[45] Scholes, R. J., Archer, S. R. (1997): Tree-grass interactions in savannas. - Annu. Rev. Ecol. Syst. 28: 517-544.

[46] SPIAF. (2007): Forest Management Inventory Standards. Operational guide. - Ministry of the Environment Conservation of Nature and Tourism, $33 \mathrm{p}$.

[47] Sys, C. (1960): Map of soils and vegetation of the Belgian Congo and Ruanda-Urundi, explanatory note of the soil map of the Belgian Congo and Ruanda-Urundi. Publications of the National Institute for the Agricultural Study of the Belgian Congo (INEAC), A. R. 22-12-33 and 21-12-39, Brussels, 96 p.

[48] Tilman, D. (1982): Resource competition and community structure. - Princeton University Press, Princeton, New Jersey, USA. 
[49] Walker, B. H., Noy-Meir, I. (1982): Aspects of stability and resilience of savanna ecosystems. - In: Huntley, B. J., Walker, B. H. (eds.) Tropical savannas: 556-590. Springer-Verlag, Berlin.

[50] Walter, H. (1971): Natural Savannas, in Ecology of Tropical and Subtropical Vegetation. - Oliver and Boyd, Edinburgh, UK.

[51] Youta, J. H. (1998): Trees against grasses: the slow invasion of the savannah by the forest in central Cameroon. - Doctoral thesis. University of Paris-Sorbonne (Paris IV), France, $241 \mathrm{p}$. 